\title{
Infection Control Measures of COVID-19 at Endoscopy Units: Knowledge and Practice of Gastrointestinal Endoscopists
}

\author{
Haidi Karam-Allah Ramadan', Hanan Sharaf EI Deen Mohammed ${ }^{2}$, \\ Adnan Ahmed Mohamed ${ }^{1}$, Ahmed Shawkat Abdelmohsen ${ }^{1}$ \\ ${ }^{1}$ Department of Tropical Medicine and Gastroenterology, Faculty of Medicine, Assiut \\ University, Assiut, Egypt. \\ ${ }^{2}$ Department of Internal Medicine, Faculty of Medicine, Assiut University, Assiut, \\ Egypt.
}

Corresponding Author Haidi Karam-Allah Ramadan

Mobile:

(+02) 01005091937

E mail:

haidikaram@aun.edu.e $g$

Key words: COVID-19; infection control; knowledge; endoscopists; personal protective equipment
Background and study aims:The health care workers at endoscopy units are at a high risk of COVID-19 infection. Several guidelines for COVID-19 infection control measures at endoscopy units are available. However, the knowledge and practice of endoscopists toward these measures are not evaluated. We aimed to assess the level of knowledge and practice of Egyptian gastrointestinal (GI) endoscopists for these measures.

Patients and Method:An online questionnaire was filled by the GI endoscopists. It consisted of 4 sections; the demographic features of the participants, pre-endoscopic infection control measures, during endoscopy on COVID-19 patients measures and postendoscopic measures. Each of the last 3 sections contained questions assessing the knowledge and practices of the endoscopists. The answers to some

\section{INTRODUCTION}

The rapid spread of the novel SARSCOV-2 or COVID-19 virus has resulted in a global pandemic. The main routes of transmission are through close or direct contact with the infected secretions or large aerosol droplets [1]. COVID-19 virus enters the target cells via the angiotensinconverting enzyme 2 (ACE2) receptor[2]. These receptors are highly expressed throughout the gastrointestinal tract at gastric, duodenal, and rectal mucosa. Therefore, these receptors act as potential viral entry receptors to the uninfected cells, and increase the possibility of fecal-oral transmission[3]. Although the confirmation of the presence of SARS-CoV-2 RNA in the stool of questions were set up as 'yes' or 'no' and the other questions required selecting the appropriate answer.

Results: A total of 120 participants completed the questionnaire. About half had endoscopic experience between 5 and 10 years. The overall correct answers regarding the knowledge were $45.6 \%$ while $62.2 \%$ for the practice. Low percent of correct answers was related to the personal protective equipment (PPE) use. About $56.7 \%$ and $58.3 \%$ found their level of knowledge and practices to be fair, respectively.

Conclusion: The knowledge of the infection control against COVID-19 was insufficient among GI endoscopists particularly PPE use. Meanwhile, the practice was relatively adequate due to hospital policies of strict application of infection control measures.

patients with COVID-19 [4], it is unclear if the viral concentration in the stool can be sufficient for the transmission of infection [3].

Therefore, gastrointestinal(GI) aerosol-generating procedures that generate small droplets in high concentrations could allow airborne transmission. These include upper GI endoscopic procedures, such as gastroduodenoscopy, enteroscopy, endoscopic ultrasound, endoscopic retrograde cholangiopancreatography (ERCP), or other procedures such as breath tests, and esophageal manometry [5].

In GI endoscopy units, several staff members work at a very short distance from the patients and frequently 
become exposed to splashes, mucus, or saliva during GI endoscopy procedures[6]. Hence, health care professionals (HCP) at endoscopy units are at increased risk of infection by COVID-19 from inhalation of airborne droplets, conjunctival contact, and potential fecal-oral transmission $[\mathbf{7}, 4]$. Therefore, flexible upper and lower GI tract endoscopies as high-risk procedures for infection transmission require the use of proper personal protective equipment (PPE) measures as well [8].

Following the COVID-19 pandemic, the American Gastroenterological Association (AGA), the European Society of Gastrointestinal Endoscopy (ESGE), and the American Society for Gastrointestinal Endoscopy (ASGE) have provided recommendations for GI endoscopic procedures and provided guidelines for endoscopic practices to ensure the highest level of protection for both patients and health care personnel against COVID-19 infection[5, 9, 10].

However, studies on the level of knowledge, and practices of HCP toward the infection control measures and applications of these published guidelines are lacking particularly in low resource setting. This will subsequently has an impact on the risk of exposure of $\mathrm{HCP}$ to infection and help to improve the health care policy in the GI endoscopy units. We aimed to assess the knowledge and practices of the Egyptian GI endoscopists toward the infection control measures in the endoscopy unit during the COVID-19 pandemic.

\section{PATIENTS AND METHODS}

In this cross-sectional study, a questionnaire was used. The questionnaire was disseminated online using Google forms between the 15th of November and 15th December, 2020. An informed consent was obtained from the participants by their agreement to participate in the study before filling the questionnaire.

The link to the questionnaire was sent through medical WhatsApp groups and other medical social media groups. A snowball sampling strategy was used. Participants were encouraged to roll out the link to as many colleagues as possible. The questionnaire was designed to assess the knowledge and practice of the Egyptian GI endoscopists either gastroenterologists, surgeons or internal medicine physicians working in different governmental GI endoscopy units all over Egypt. After acceptance to participate they filled up the questionnaire which included a set of several questions that appeared in a sequential manner over four sections.

The first section was regarding the demographic data of the participants while, the next three sections were concerned with the assessment of knowledge and practice toward the infection control measures; pre-endoscopy, during endoscopy on a COVID-19 patient and postendoscopy, respectively.

The questionnaire was designed on the basis of relevant guidelines such as AGA, ASGE, ESGE and previous researches on COVID-19 infection control measures of endoscopy[11, 8-10, 5, 12, 6, 13]. The answers to some questions were set up as 'yes' or 'no' and the other questions required selecting the appropriate answer. The respondents chose the answer based on their own knowledge and were encouraged to give only one answer to each question. The questionnaire was given to relevant experts in the field of gastroenterology, statistics and epidemiology to confirm its validity. The internal consistency of questions obtained in Cronbach's alpha was 0.73. Hence, the reliability was confirmed. There were 18 questions regarding the knowledge and 12 questions regarding the practices (appendix A). For the knowledge questions, incorrect or uncertain (do not know) responses were given a 0 score, while 1 point was given for choosing the correct answer. The expected maximum total knowledge score was 2160 . For the practice sections, a score of 1 was given for choosing the answer reflecting a positive attitude or good practice and 0 for answers reflecting poor practice. The expected maximum total practices score was 1440.

\section{Statistical analysis:}

Data was collected and analyzed using SPSS (Statistical Package for the Social Science, version 20, IBM, and Armonk, New York). Continuous data was expressed in form of mean \pm SD while categorical data was expressed in form of number and frequency (percentage). $\mathrm{Chi}^{2}$ test was used to compare categorical data. Linear regression analysis was performed to detect the factors associated with inadequate knowledge. $\mathrm{P}$ value was considered significant if $<0.05$. 


\section{RESULTS}

\section{Demographic features of the participants:}

In this study a total of 120 participants responded to the questionnaire. As shown in table 1, the demographic features of the participants revealed that there were 88 males $(73.3 \%$ ) and 32 females (26.7\%). Their mean age was $34.2 \pm 3.8$ years. About two third were gastroenterologists and about half had endoscopic experience between 5 and 10 years $(51.7 \%)$.

\section{Assessment of the level of knowledge toward the infection control measures:}

\subsection{Pre-endoscopic infection control measures:}

As shown in table 2, about half of the participants $(53.3 \%)$ reported correctly that the distance between patients at the endoscopy waiting room should be at least 2 meters. On asking about the number of essential family members accompanying the patient, more than two third selected the answer of 1 member (71.7\%). When asking about the endoscopic procedure requiring the use of personal protective equipment (PPE), 96 participants (80\%) selected both upper and lower endoscopy. The majority $(90 \%)$ answered that patients either COVID or non-COVID having lower endoscopic procedure should wear mask during endoscopy. About $58.3 \%$ of participants mentioned that they did not receive adequate education or enhanced training related to the use of PPE (fig.1A).

\subsection{During endoscopy on a COVID-19 patient:}

About $88.3 \%$ considered that aerosolization of the virus could occur during insertion and removal of instruments through the endoscopic channels and $78.3 \%$ considered that air inflation should be reduced during colonoscopy. About two third $(63.3 \%)$ found that wearing either goggles or face shield is sufficient for their protection. About $45 \%$ could identify the correct order of wearing PPE while about one third (30\%) did not know. About two third (63.3\%) thought that the maximum number of nurses should be present during endoscopy is 2 while $33.3 \%$ selected the correct answer of 1 nurse. By asking about the endoscopic shield, 85\% answered that they do not know about it. About two third (63.3\%) answered that they should not stay in the room during tracheal intubation if required by the anesthesiologist (table 3 ).

\subsection{Post-endoscopic measures:}

About one third of the participants (30\%) did not know where they should take off their PPE after performing the endoscopy while $10 \%$ answered correctly. Moreover, $40 \%$ did not know the correct order of removing their PPE and only $3.3 \%$ selected the correct order. More than half $(58.3 \%)$ thought that the endoscopy requires extra-sterilization after endoscopy on a COVID19 patient. Forty percent did not know for how long the virus remains viable after aerosolization while $8.3 \%$ selected the correct answer of 3 hours. More than half (58.3\%) considered that Cidex ${ }^{\circledR}$ is the disinfectant should be used for the surfaces in the endoscopy room while $30 \%$ selected sodium hypochlorite correctly. More than half $(56.7 \%)$ did not know when to bring another patient in the room after endoscopy on a COVID-19 patient (table 4).

3. Assessment of the practice toward the infection control measures:

\subsection{Pre-endoscopic infection control measures:}

As shown in table 5, the majority of participants $(85 \%)$ reported that they measure the temperature of the patient or ask about symptoms of COVID-19 before endoscopy. About 71.7\% reported that they remove watches, rings or other forms of jewelry before entering the endoscopy room. However, about two third $(63.3 \%)$ did not consider including a paragraph in the consent form regarding COVID-19 potential risk of transmission.

\subsection{During endoscopy on a COVID-19 patient:}

Half of the participants (50\%) use surgical masks, $53.3 \%$ use two pairs of gloves, $68.3 \%$ use disposable gowns not aprons, $68.3 \%$ use face shield without goggles while $16.7 \%$ do not use either face shield or goggles and $33.3 \%$ use disposable overshoes. In the majority of the units they work in $(90 \%)$ there is no negative pressure room. On asking if they would accept to use disinfected or re-used N95 mask or to use surgical mask, $73.3 \%$ preferred to use surgical masks (table 6).

\subsection{Post-endoscopic measures:}

About two third $(63.3 \%)$ mentioned that they write the endoscopy report with the required instruction as a method of patient discharge 
discussion while $18.3 \%$ preferred direct communication with the patient. More than two third $78.3 \%$ mentioned that they would follow up the patients for 1-2 weeks after endoscopy for the development of COVID-related symptoms. Seventy five percent reported that their endoscopy units do not have a separate entrance and exit gates for the patients (table 7).

When asking a question on self-assessment of the participant's level of knowledge and practices regarding the infection control measures graded from very poor, poor, fair, good and very good; $56.7 \%$ and $58.3 \%$ found it to be fair, respectively (fig. 1B).

The overall total score for the correct answers for knowledge and practice showed that the correct answers for the knowledge were recorded by 984 out of $2160(45.6 \%)$ of the participants while 896 out of $1440(62.2 \%)$ answered correctly in the practice questions.

On comparison between the self-assessment level of training related to PPE according to the demographic features, there was no significant difference regarding the gender, the specialty or the years of endoscopic experience of the participants. However, the majority of participants (70 out of 120) found they had inadequate training level (table 8). On performing regression analysis, no significant factor was associated with the observed inadequate knowledge.

Table 1: The demographic features of the studied participants.

\begin{tabular}{|l|c|}
\hline \multicolumn{1}{|c|}{ Item } & Number (\%) \\
\hline Gender: & \\
Female & $32(26.7)$ \\
Male & $88(73.3)$ \\
\hline Age(mean \pm SD) & 34.2 y \pm 3.8 \\
\hline Specialties: & $78(65)$ \\
$\quad$ Gastroenterology & $20(16.7)$ \\
Surgery & $22(18.3)$ \\
$\quad$ Internal medicine & $5.7 \pm 3.5$ \\
\hline Years of endoscopic & $48(40)$ \\
Experience(mean \pm SD) & $62(51.7)$ \\
<5 years & $10(8.3)$ \\
5- 10 years & $12(10)$ \\
\hline 10 years & $46(38.3)$ \\
\hline Latest academic position/ title: & $24(20)$ \\
\hline Resident & $6(5)$ \\
\hline Assistant lecturer & $18(15)$ \\
\hline Lecturer & $14(11.7)$ \\
\hline Assistant professor & \\
\hline Specialist & \\
Consultant & \\
\hline
\end{tabular}


Table 2: The knowledge questions toward the pre-endoscopic infection control measures against COVID-19.

\begin{tabular}{|c|c|c|}
\hline Title of Questions & Answers of Participants (n,\%) & $\begin{array}{c}\text { Correct answer } \\
(\mathbf{n}, \%)\end{array}$ \\
\hline $\begin{array}{l}\text { 1-The distance between patients at the } \\
\text { endoscopy waiting room. }\end{array}$ & $\begin{array}{c}1 \text { meter }(38,31.7) \\
2 \text { meters }(64,53.3) \\
3 \text { meters }(8,6.7) \\
\text { I do not know }(10,8.3) \\
\end{array}$ & $64(53.3)$ \\
\hline $\begin{array}{l}\text { 2-The number of essential family members } \\
\text { that should accompany the patient. }\end{array}$ & $\begin{array}{l}1 \text { member }(86,71.7) \\
2 \text { members }(30,25) \\
3 \text { members }(4,3.3)\end{array}$ & $86(71.7)$ \\
\hline $\begin{array}{l}\text { 3-The GI endoscopic procedures require } \\
\text { the use of PPE. }\end{array}$ & $\begin{array}{c}\text { Upper GI procedure }(22,18.3) \\
\text { Lower GI procedure }(0) \\
\text { Both upper and lower procedure }(96,80) \\
\text { Both are not risky }(0) \\
\text { I do not know }(2,1.7) \\
\end{array}$ & $96(80)$ \\
\hline $\begin{array}{l}\text { 4-Do patients either COVID or non- } \\
\text { COVID undergoing lower endoscopy } \\
\text { should wear mask? }\end{array}$ & $\begin{array}{c}\text { Yes }(108,90) \\
\text { No }(12,10)\end{array}$ & $108(90)$ \\
\hline $\begin{array}{l}\text { 5-Did you receive adequate education or } \\
\text { enhanced training to the use of PPE? }\end{array}$ & $\begin{array}{l}\text { Yes }(50,41.7) \\
\text { No }(70,58.3)\end{array}$ & $50(41.7)$ \\
\hline
\end{tabular}

GI: gastrointestinal, PPE: personal protective equipment.

Table 3: The knowledge questions toward the infection control measures against COVID-19 during endoscopy on a COVID-19 patient.

\begin{tabular}{|c|c|c|}
\hline Title of Questions & Answers of Participants (n,\%) & Correct answer (n,\%) \\
\hline $\begin{array}{l}\text { 1- Can aerosolization of the virus } \\
\text { occur during insertion and } \\
\text { removal of instruments through } \\
\text { the endoscopic channel? }\end{array}$ & $\begin{array}{l}\text { Yes(106, 88.3) } \\
\text { No(14, 11.7) }\end{array}$ & $106(88.3)$ \\
\hline $\begin{array}{l}\text { 2- Should air inflation be reduced } \\
\text { during colonoscopy? }\end{array}$ & $\begin{array}{l}\text { Yes }(94,78.3) \\
\text { No }(26,21.7) \\
\end{array}$ & $94(78.3)$ \\
\hline $\begin{array}{l}\text { 3- Should you wear goggles and face } \\
\text { shield together? or one of them? }\end{array}$ & $\begin{array}{c}\text { Both are sufficient }(44,36.7) \\
\text { One of them is sufficient }(76,63.3)\end{array}$ & $76(63.3)$ \\
\hline 4- The correct order of wearing PPE. & $\begin{array}{c}\text { First pair of gloves, gown, overhead, } \\
\text { masks, face shield/goggles }(54,45) \\
\text { Other choices (see appendix) }(30,25) \\
\text { I do not know }(36,30)\end{array}$ & $54(45)$ \\
\hline $\begin{array}{l}\text { 5- The maximum numbers of nurses } \\
\text { that should be present during } \\
\text { endoscopy. }\end{array}$ & \begin{tabular}{|c|}
1 nurse $(40,33.3)$ \\
2 nurses $(76,63.3)$ \\
3 nurses $(4,3.3)$ \\
More than $3(0)$ \\
\end{tabular} & $40(33.3)$ \\
\hline $\begin{array}{l}\text { 6- Do you know the endoscopic } \\
\text { shield? }\end{array}$ & $\begin{array}{c}\text { Yes }(18,15) \\
\text { No }(102,85)\end{array}$ & $18(15)$ \\
\hline $\begin{array}{l}\text { 7- If tracheal intubation is required on } \\
\text { the patient should you stay in the } \\
\text { room? }\end{array}$ & $\begin{array}{l}\text { Yes }(44,36.7) \\
\text { No }(76,63.3)\end{array}$ & $76(63.3)$ \\
\hline
\end{tabular}


Table 4:The knowledge questions toward the post-endoscopic infection control measures against COVID-19.

\begin{tabular}{|c|c|c|}
\hline Title of Questions & Answers of Participants (n, \%) & $\begin{array}{c}\text { Correct answer } \\
(\mathbf{n}, \%)\end{array}$ \\
\hline $\begin{array}{l}\text { 1- The place where you should } \\
\text { remove your PPE } \\
\text { endoscopic procedure. }\end{array}$ & $\begin{array}{c}\text { Gloves and gowns are removed inside the endoscopy } \\
\text { room and other PPE outside }(12,10) \\
\text { Other choices(see appendix) }(72,60) \\
\text { I do not know }(36,30)\end{array}$ & $12(10)$ \\
\hline $\begin{array}{l}\text { 2- The correct order of removing } \\
\text { your PPE. }\end{array}$ & $\begin{array}{c}\text { Gowns, second pair of gloves, face shield/goggles, } \\
\text { mask, overhead }(4,3.3) \\
\text { Other choices (see appendix)(68, 56.7) } \\
\text { I do not know }(48,40)\end{array}$ & $4(3.3)$ \\
\hline $\begin{array}{l}\text { 3- Do you think the endoscope } \\
\text { requires extra sterilization after } \\
\text { endoscopy on COVID-19 patient }\end{array}$ & $\begin{array}{c}\text { Yes }(70,58.3) \\
\text { No }(38,31.7) \\
\text { I do not know }(12,10) \\
\end{array}$ & $38(31.7)$ \\
\hline $\begin{array}{l}\text { 4- For how long the virus remains } \\
\text { viable after aerosolization? }\end{array}$ & $\begin{array}{c}2 \text { hours }(16,13.3) \\
3 \text { hours }(10,8.3) \\
4 \text { hours }(46,38.3) \\
\text { I do not know }(48,40) \\
\end{array}$ & $10(8.3)$ \\
\hline $\begin{array}{l}5 \text { - The disinfectant used for surfaces } \\
\text { in endoscopy room r after } \\
\text { endoscopy on COVID-19 patient. }\end{array}$ & $\begin{array}{c}\text { Cidex }{ }^{\circledR}(70,58.3) \\
\text { Water and soap }(6,5) \\
\text { Chlorine }(36,30) \\
\text { I do not know }(8,6.7) \\
\end{array}$ & $36(30)$ \\
\hline $\begin{array}{l}\text { 6- When can you bring another } \\
\text { patient in the room after } \\
\text { endoscopy on COVID-19 patient? }\end{array}$ & $\begin{array}{c}1 \text { hour if not using a negative pressure room }(16,13.3) \\
\text { Other choices(see appendix) }(36,30) \\
\text { I do not know }(68,56.7)\end{array}$ & $16(13.3)$ \\
\hline
\end{tabular}

Table 5: The practices toward the pre-endoscopic infection control measures against COVID-19 questions.

\begin{tabular}{|l|c|c|}
\hline \multicolumn{1}{|c|}{ Title of Question } & $\begin{array}{c}\text { Answers of the } \\
\text { participants (n, \%) }\end{array}$ & $\begin{array}{c}\text { Correct } \\
\text { answer (n,\%) }\end{array}$ \\
\hline $\begin{array}{l}\text { 1- Do you measure the patient temperature or ask for symptoms of } \\
\text { COVID-19 before endoscopic procedure? }\end{array}$ & $\begin{array}{c}\text { Yes (102, 85) } \\
\text { No (18,15) }\end{array}$ & 102(85) \\
\hline $\begin{array}{l}\text { 2- Do you remove your watches, rings, necklaces or other forms of } \\
\text { jewelry before entering the endoscopy room? }\end{array}$ & $\begin{array}{c}\text { Yes(86,71.7) } \\
\text { No(34,28.3) }\end{array}$ & $86(71.7)$ \\
\hline $\begin{array}{l}\text { 3- Do you consider including a paragraph in the endoscopy consent } \\
\text { form regarding COVID-19 potential risk of transmission? }\end{array}$ & $\begin{array}{c}\text { Yes(44,36.7) } \\
\text { No(76, 63.3) }\end{array}$ & $44(36.7)$ \\
\hline
\end{tabular}

Table 6: The practices during endoscopy on COVID-19 patients questions.

\begin{tabular}{|c|c|c|}
\hline Title of Question & Answers of the participants $(n, \%)$ & Correct answer (n,\%) \\
\hline 1- The type of mask used. & $\begin{array}{c}\mathrm{N} 95(60,50) \\
\text { Surgical mask }(60,50) \\
\end{array}$ & $60(50)$ \\
\hline $\begin{array}{l}\text { 2- The use of single or two pairs of } \\
\text { gloves. }\end{array}$ & $\begin{array}{l}\text { Single pair of gloves }(56,46.7) \\
\text { Two pair of gloves }(64,53.3)\end{array}$ & $64(53.3)$ \\
\hline 3- The type of gowns used. & $\begin{array}{c}\text { Disposable gown only }(82,68.3) \\
\text { Apron only }(8,6.7) \\
\text { Both }(30,25) \\
\end{array}$ & $112(93.3)$ \\
\hline 4- The use of goggles or face shield. & $\begin{array}{c}\text { Face shield }(82,68.3) \\
\text { Goggles }(4,3.3) \\
\text { Both }(14,11.7) \\
\text { None }(20,16.7) \\
\end{array}$ & $100(83.3)$ \\
\hline $\begin{array}{l}\text { 5- The use of disposable overshoes } \\
\text { or work boots. }\end{array}$ & $\begin{array}{c}\text { Disposable overshoes }(40,33.3) \\
\text { Work Boots }(36,30) \\
\text { Both }(8,6.7) \\
\text { None }(36,30) \\
\end{array}$ & $84(70)$ \\
\hline $\begin{array}{l}\text { 6- Do you use negative pressure } \\
\text { room? }\end{array}$ & $\begin{array}{c}\text { Yes }(12,10) \\
\text { No }(108,90) \\
\end{array}$ & $12(10)$ \\
\hline
\end{tabular}


Table 7: The practices toward the post-endoscopic infection control measures against COVID-19 questions.

\begin{tabular}{|c|c|c|}
\hline Title of Question & Answers of the participants (n, \%) & Correct answer (n,\%) \\
\hline $\begin{array}{l}\text { 1- How the patients discharge } \\
\text { discussion takes place? }\end{array}$ & $\begin{array}{c}\text { Direct communication }(22,18.3) \\
\text { Telemedicine }(10,8.3) \\
\text { Without communication }(12,10) \\
\text { Writing the report with the required } \\
\text { instruction }(76,63.3)\end{array}$ & 108(90) \\
\hline $\begin{array}{l}\text { 2- For how long will you follow up the } \\
\text { patient after endoscopy for } \\
\text { development of COVID-19 related } \\
\text { symptoms? }\end{array}$ & $\begin{array}{c}\text { 1- } 2 \text { weeks }(94,78.3) \\
3 \text { weeks }(2,1.7) \\
\text { I do not follow up patients }(24,20)\end{array}$ & 94(78.3) \\
\hline $\begin{array}{l}\text { 3- Do the patients have separate } \\
\text { entrance and exit gates in the unit? }\end{array}$ & $\begin{array}{l}\text { Yes }(30,25) \\
\text { No }(90,75)\end{array}$ & $30(25)$ \\
\hline
\end{tabular}

Table 8: Difference of the self-assessment of training related to PPE according to the demographic features of the studied participants.

\begin{tabular}{|c|c|c|c|}
\hline \multirow[b]{2}{*}{ Item } & \multicolumn{2}{|c|}{ Level of Training } & \multirow[b]{2}{*}{ P-value } \\
\hline & $\begin{array}{c}\text { Adequate } \\
(\mathbf{n}=50) \\
(\mathbf{n}, \%)\end{array}$ & $\begin{array}{c}\text { Inadequate } \\
(\mathbf{n}=70) \\
(\mathbf{n}, \%)\end{array}$ & \\
\hline $\begin{aligned} \text { Gender: } & \\
& \text { Female } \\
& \text { Male }\end{aligned}$ & $\begin{array}{l}16(32) \\
34(68)\end{array}$ & $\begin{array}{l}16(22.9) \\
54(77.1)\end{array}$ & 0.4 \\
\hline $\begin{array}{l}\text { Specialty: } \\
\text { Gastroenterology } \\
\text { Surgery } \\
\text { Internal Medicine }\end{array}$ & $\begin{array}{c}34(68) \\
4(8) \\
12(24)\end{array}$ & $\begin{array}{l}44(62.9) \\
16(22.9) \\
10(14.3)\end{array}$ & 0.3 \\
\hline $\begin{array}{l}\text { Years of endoscopic experience: } \\
<5 \text { years } \\
5-10 \text { years } \\
>10 \text { years }\end{array}$ & $\begin{array}{c}24(48) \\
22(44) \\
4(8)\end{array}$ & $\begin{array}{c}24(34.3) \\
40(57.1) \\
6(8.6)\end{array}$ & 0.6 \\
\hline
\end{tabular}

Table 9: Regression analysis of the factors associated with inadequate knowledge toward the infection control measures against COVID-19.

\begin{tabular}{|c|c|c|c|c|}
\hline Variables & OR & P value & \multicolumn{2}{|c|}{$95 \%$ Confidence Interval } \\
\cline { 4 - 5 } & & & Lower Level & Upper Level \\
\hline Gender & $-0.011-$ & 0.940 & $-1.440-$ & 1.336 \\
\hline Age & $-0.001-$ & 0.998 & $-0.300-$ & 0.299 \\
\hline $\begin{array}{c}\text { Years of endoscopic } \\
\text { experience }\end{array}$ & $-0.084-$ & 0.768 & $-0.0383-$ & 0.284 \\
\hline Specialty & $-0.051-$ & 0.723 & $-0.906-$ & 0.632 \\
\hline Academic position & 0.072 & 0.650 & $-0.423-$ & 0.673 \\
\hline
\end{tabular}




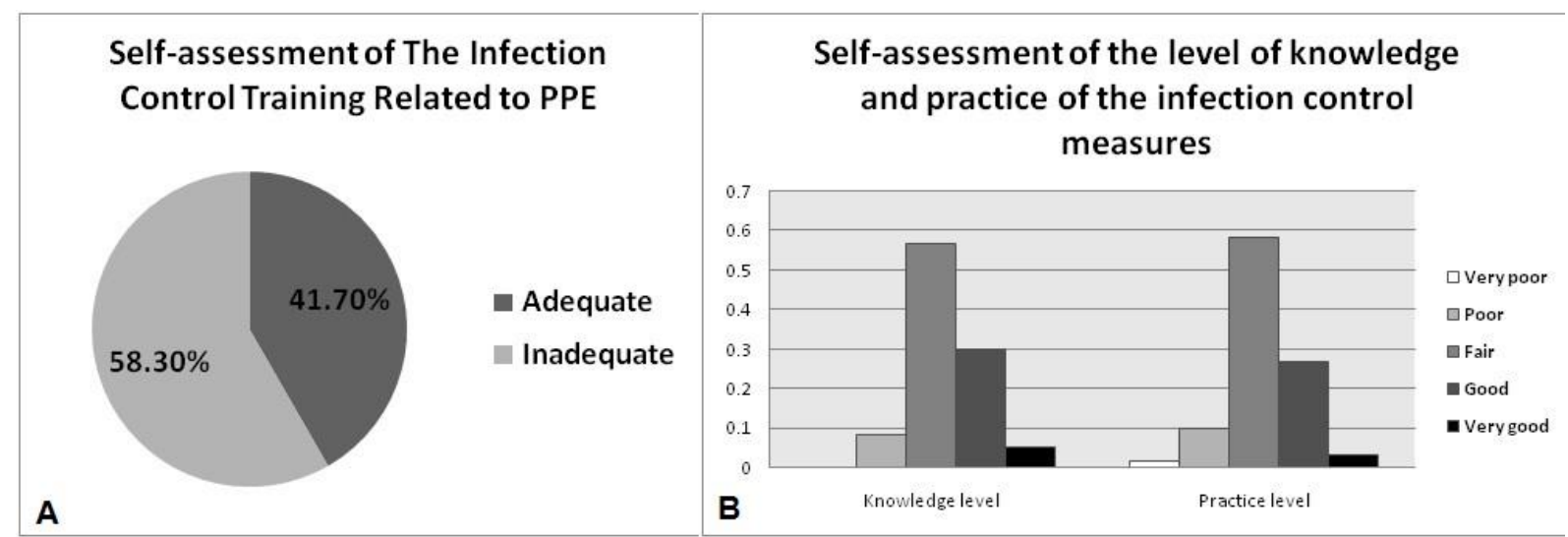

Figure 1: A: The percentage of self-assessment of the participants regarding the training on the use of PPE. B: The percentage of self-assessment of the participant's level of knowledge and practices regarding the infection control measures.

\section{DISCUSSION}

The HCP are at high risk of COVID-19 infection. The global estimates of COVID-19 infection among front-line health-care professional reached $10-20 \%$ of all diagnosed cases $[14,15]$. The prevalence of COVID-19 among $\mathrm{HCP}$ in an Egyptian gastroenterology tertiary care hospital was $13.5 \%$ [16].

The rapid global rise of COVID-19 spread has forced a temporary postponement of several endoscopic procedures particularly the elective ones. Currently, several GI endoscopy units started gradual resumption of their activities [10]. Several guidelines regarding the infection control measures at endoscopy units were published to guard against the risk of COVID-19 transmission among HCP and patients. Yet, the knowledge and practices of HCP toward these guidelines were not properly assessed.

To the best of our knowledge, this is the first study to evaluate knowledge, and practice of the GI endoscopists toward the infection control measures against COVID-19 transmission at endoscopy units.

In this study, half of the participants had endoscopic experience between 5-10 years. However, the answers regarding the knowledge level showed that less than half of the participants had an adequate level of knowledge; $45.6 \%$ answered correctly. The lowest percent of correct answers were observed in the questions of post-endoscopic infection control measures particularly related to PPE. The knowledge regarding the cleaning and disinfection was inadequate. About one third of the participants believed that after endoscopy on a COVID-19 patient the endoscope requires sterilization more than usual and the Cidex ${ }^{\circledR}$ is required for cleaning the surfaces. Kampf et al reported that effective inactivation of coronaviruses, including SARS-CoV, could be done by standard biocidal agents, which are active ingredients in the currently used endoscopic disinfecting solutions[17]. Therefore, the current guidelines recommended that no changes are required to established reprocessing procedures for endoscopes and accessories[10].

Additionally, in the current study, the questions related to the knowledge of PPE use showed an inadequate level of knowledge of HCP. In regression analysis, no factors could be found to be associated with this inadequate level. Meanwhile, more than half of the participants reported that they did not receive adequate training related to the use of PPE. This could be a major factor resulting in an inadequate level of knowledge in our cohort.

PPE is a crucial method of infection control against COVID-19 and proper training on the donning and doffing of PPE is extremely important for maximum protection of the HCP.

Full PPE includes hair net or overhead, face shield or goggles, surgical masks or N95 respirators or equivalent, gowns, and gloves. In one study it was found that in the high-incidence areas of COVID-19, the incidence of infection among GI endoscopists was higher than in lowincidence areas (21\% vs 9.5\%) and most COVID-19 infections occurred at the onset of the epidemic, when protective measures had not been implemented[18].

Regarding the practice toward the infection control measures in this study, $62.2 \%$ answered correctly. Although Egypt is a country of low- 
resource setting, the policy of implementation of strict infection control measures by the endoscopy units warrants the availability of PPE at these units to protect $\mathrm{HCP}$ and patients.

In the current study, the N95 mask was used by $50 \%$, disposable gowns by $93.3 \%$, goggles or face shield by $83.3 \%$, overshoes or work boots by $70 \%$ while only $10 \%$ had negative pressure room in their units. In a similar study, Alboraie et al multi-center study assessed the impact of COVID-19 on GI units, and found that N95 masks were used in $57.1 \%$ of units, isolation gowns in $74.2 \%$, head-covers in $8.5 \%$, and most of these centers $(69 \%)$ had no negative pressure rooms[19]. Another multicenter Italian study by Repici et al reported that when performing endoscopic procedures on COVID-19 patients, a surgical mask was used in $22 \%$ of endoscopy units; N95 in 97.6\%; a double pair of gloves in $87.8 \%$; hairnets in $95.1 \%$; goggles/face shields in 97.6\%; water-resistant gowns in $87.8 \%$ and 7 endoscopy units $(17.1 \%)$ had available negativepressure room[20].

In one study it was reported that coronaphobia can cause different psychological and mental impacts on the frontline HCP. Higher burnout frequency during COVID-19 pandemic should also be reduced. These mental factors can influence the knowledge and practice of infection control amidst the pandemic. Therefore, planning for training workshops regarding mental health will to improve the coping mechanisms of these HCP [21].

Our study showed there was a gap between the knowledge and the practice of the infection control measures against COVID-19 among HCP. This is similar to Grima et al who assessed the knowledge and practice of health professional toward COVID-19 in university hospitals and found an acceptable level of the application of the participants regarding the recommended protective measures but there was a significant gap between knowledge and behavioral practice for wearing masks and gloves[22].

The small sample size is one of the limitations of this study. However, the governmental GI endoscopic units in Egypt are in a limited number. These units apply the policy of strict infection control measures according to the national guidelines. Another limitation is the low number of participants with higher endoscopic experience. However, in Egypt after the COVID-
19 pandemic, most of the endoscopists with higher experience reduced their work activity at the endoscopy units. Further international studies should be conducted on a global level for evaluation of the difference between areas of high and low resource settings.

In conclusion, the knowledge of the infection control measures against COVID-19 was insufficient among GI endoscopists. Their knowledge toward the PPE regarding where or how to remove it was very inadequate which put these categories of health care professionals at a high risk of getting the infection by COVID-19. Meanwhile, the practice of the infection control measures was relatively adequate mostly due to hospital policies of strict application of infection control measures and obligatory use of PPE. Therefore, proper training of the medical staff on PPE use should be conducted by the hospital leadership and infection control units with the development of a common algorithm for PPE use to reduce the gap between knowledge and practice. Proper evaluation of these training workshops should also be planned.

Declaration of Conflicting Interests: Authors declare that there is no conflict of interest.

Funding: This research did not receive any specific grant from funding agencies in the public, commercial, or not-for-profit sectors.

\section{Ethical considerations:}

This study was approved by the Ethical Committee of the Faculty of Medicine, Assiut University and registered in Clinical trial by ID (NCT04479345).

\section{REFERENCES}

1. Yang H, Duan G. Analysis on the epidemic factors for the corona virus disease. Zhonghua yu Fang yi xue za zhi. Chinese Journal of Preventive Medicine2020;54:E021-E021.

2. Wu F, Zhao S, Yu B, Chen Y-M, Wang W, Song Z-G, et al. A new coronavirus associated with human respiratory disease in China. Nature 2020;579:265-269.

3. Xiao F, Tang M, Zheng X, Liu Y, Li X, Shan H. Evidence for gastrointestinal infection of SARSCoV-2. Gastroenterology 2020;158:1831-1833. e3.

4. Gu J, Han B, Wang J. COVID-19: gastrointestinal manifestations and potential fecal-oral transmission. Gastroenterology 2020;158:1518-1519. 
5. Sultan S, Lim JK, Altayar O, Davitkov P, Feuerstein JD, Siddique SM, et al. AGA Institute rapid recommendations for gastrointestinal procedures during the COVID-19 pandemic. Gastroenterology2020;159:739-758.

6. Philip M, Lakhtakia S, Aggarwal R, Madan K, Saraswat V, Makharia G. Joint Guidance from SGEI, ISG and INASL for Gastroenterologists and Gastrointestinal Endoscopists on the Prevention, Care and Management of patients with COVID-19. Journal of Clinical and Experimental Hepatology 2020.

7. Huang C, Wang Y, Li X, Ren L, Zhao J, Hu Y, et al. Clinical features of patients infected with 2019 novel coronavirus in Wuhan, China. The Lancet 2020;395:497-506.

8. Sinonquel P, Roelandt $\mathrm{P}$, Demedts $\mathrm{I}$, Van Gerven L, Vandenbriele C, Wilmer A, et al. COVID-19 and gastrointestinal endoscopy: what should be taken into account? Digestive Endoscopy 2020.

9. Gralnek IM, Hassan C, Beilenhoff U, Antonelli G, Ebigbo A, Pellisè M, et al. ESGE and ESGENA Position Statement on gastrointestinal endoscopy and the COVID-19 pandemic. Endoscopy 2020;52:483.

10. Hennessy B, Vicari J, Bernstein B, Chapman F, Khaykis I, Littenberg G, et al. Guidance for resuming GI endoscopy and practice operations after the COVID-19 pandemic. Gastrointestinal Endoscopy 2020.

11. Huang Q, Liu G, Wang J, Duan T, Feng Y, Lin $\mathrm{X}$, et al. Control measures to prevent Coronavirus disease 2019 (COVID-19) pandemic in endoscopy centers: a multi-centre study. Digestive Endoscopy 2020.

12. Lui RN, Wong SH, Sánchez-Luna SA, Pellino G, Bollipo S, Wong MY, et al. Overview of guidance for endoscopy during the coronavirus disease 2019 pandemic. Journal of Gastroenterology and Hepatology 2020;35:749759.

13. Elli L, Rimondi A, Scaramella L, Topa M, Vecchi M, Mangioni D, et al. Endoscopy during the Covid-19 outbreak: experience and recommendations from a single center in a highincidence scenario. Digestive and Liver Disease 2020.
14. Characteristics of Health Care Personnel with COVID-19 - United States, February 12-April 9, 2020. MMWR Morb Mortal Wkly Rep 2020;69:477-481.

15. Lazzerini M, Putoto G. COVID-19 in Italy: momentous decisions and many uncertainties. Lancet Glob Health. 2020.

16. Kassem AM, Talaat H, Shawky S, Fouad R, Amer K, Elnagdy $\mathrm{T}$, et al. SARS-CoV-2 infection among healthcare workers of a gastroenterological service in a tertiary care facility. Arab Journal of Gastroenterology 2020.

17. Kampf G, Todt D, Pfaender S, Steinmann E. Persistence of coronaviruses on inanimate surfaces and their inactivation with biocidal agents. Journal of Hospital Infection2020;104:246-251.

18. Barret M, Gronier O, Chaussade S. COVID-19 transmission among gastrointestinal endoscopists. Gastroenterology 2020.

19. Alboraie M, Piscoya A, Tran QT, Mendelsohn RB, Butt AS, Lenz L, et al. The global impact of COVID-19 on gastrointestinal endoscopy units: An international survey of endoscopists. Arab Journal of Gastroenterology 2020;21:156-161.

20. Repici A, Pace F, Gabbiadini R, Colombo M, Hassan C, Dinelli M. Endoscopy Units and the Coronavirus Disease 2019 Outbreak: A Multicenter Experience From Italy. Gastroenterology2020;159:363-366.

21. Asghar MS, Yasmin F, Alvi H, Shah SMI, Malhotra K, Farhan SA, et al. Assessing the Mental Impact and Burnout among Physicians during the COVID-19 Pandemic: A Developing Country Single-Center Experience. The American Journal of Tropical Medicine and Hygiene 2021;1.

22. Girma S, Alenko A, Agenagnew L. Knowledge and Precautionary Behavioral Practice Toward COVID-19 Among Health Professionals Working in Public University Hospitals in Ethiopia: A Web-Based Survey. Risk Management and Healthcare Policy 2020;13:1327. 